\title{
Spinal cord stimulation for complex regional pain syndrome
}

\section{type 1 with dystonia: a case report and discussion of the}

\section{literature [version 1; peer review: 2 approved]}

\author{
Caroline Voet ${ }^{1,2}$, Bernard le Polain de Waroux ${ }^{2-5}$, Patrice Forget (iD)2-5, \\ Ronald Deumens ${ }^{4,5}$, Etienne Masquelier ${ }^{1,2,4}$ \\ ${ }^{1}$ Rehabilitation Medicine, Université Catholique de Louvain, Brussels, Belgium \\ ${ }^{2}$ Multidisciplinary Reference Unit for Chronic Pain, Université Catholique de Louvain, Brussels, Belgium \\ ${ }^{3}$ Anaesthesiology, Cliniques Universitaires Saint-Luc, Université Catholique de Louvain, Brussels, Belgium \\ ${ }^{4}$ Institute of Neuroscience, Université Catholique de Louvain, Brussels, Belgium \\ ${ }^{5}$ Neuropharmacology Unit, pole CEMO, Université Catholique de Louvain, Brussels, Belgium
}

V1 First published: 30 Apr 2014, 3:97

https://doi.org/10.12688/f1000research.3771.1

Latest published: 30 Apr 2014, 3:97

https://doi.org/10.12688/f1000research.3771.1

\section{Abstract}

Background: Complex Regional Pain Syndrome type 1 (CRPS-1) is a debilitating chronic pain disorder, the physiopathology of which can lead to dystonia associated with changes in the autonomic, central and peripheral nervous system. An interdisciplinary approach (pharmacological, interventional and psychological therapies in conjunction with a rehabilitation pathway) is central to progress towards pain reduction and restoration of function.

Aim: This case report aims to stimulate reflection and development of mechanism-based therapeutic strategies concerning CRPS associated with dystonia.

Case description: A 31 year old female CRPS-1 patient presented with dystonia of the right foot following ligamentoplasty for chronic ankle instability. She did not have a satisfactory response to the usual therapies. Multiple anesthetic blocks (popliteal, epidural and intrathecal) were not associated with significant anesthesia and analgesia. Mobilization of the foot by a physiotherapist was not possible. A multidisciplinary approach with psychological support, physiotherapy and spinal cord stimulation (SCS) brought pain relief, rehabilitation and improvement in the quality of life.

Conclusion: The present case report demonstrates the occurrence of multilevel (peripheral and central) pathological modifications in the nervous system of a CRPS-1 patient with dystonia. This conclusion is based on the patient's pain being resistant to anesthetic blocks at different levels and the favourable, at least initially, response to SCS. The importance of the bio-psycho-social model is also suggested, permitting behavioural change.

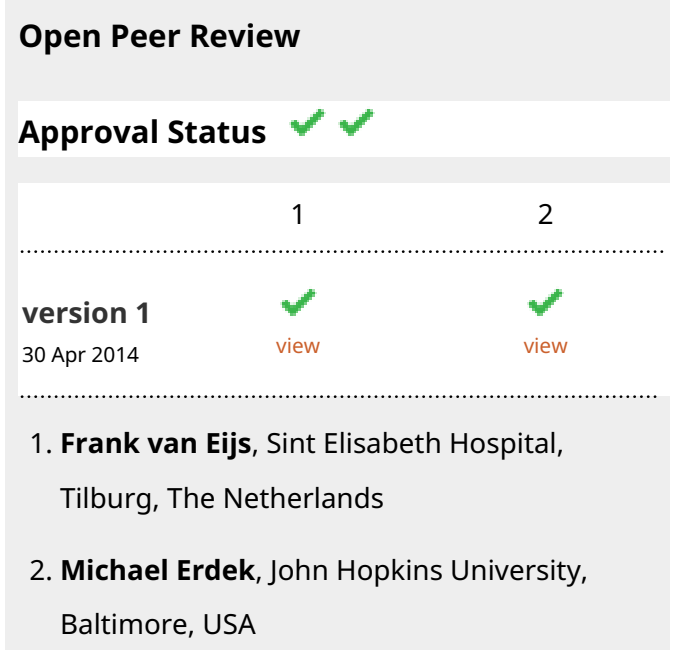

Any reports and responses or comments on the article can be found at the end of the article. 
Corresponding author: Patrice Forget (forgetpatrice@yahoo.fr)

Competing interests: No competing interests were disclosed.

Grant information: The author(s) declared that no grants were involved in supporting this work.

Copyright: $\odot 2014$ Voet $C$ et al. This is an open access article distributed under the terms of the Creative Commons Attribution License, which permits unrestricted use, distribution, and reproduction in any medium, provided the original work is properly cited. Data associated with the article are available under the terms of the Creative Commons Zero "No rights reserved" data waiver (CC0 1.0 Public domain dedication).

How to cite this article: Voet C, le Polain de Waroux B, Forget $P$ et al. Spinal cord stimulation for complex regional pain syndrome type 1 with dystonia: a case report and discussion of the literature [version 1; peer review: 2 approved] F1000Research $2014,3: 97$ https://doi.org/10.12688/f1000research.3771.1

First published: 30 Apr 2014, 3:97 https://doi.org/10.12688/f1000research.3771.1 


\section{Introduction}

Complex regional pain syndrome (CRPS) is a chronic pain disorder that usually affects the lower or upper extremities. Two types of CRPS have been described: CRPS type 1 (CRPS-1; reflex sympathetic dystrophy), normally triggered by a painful trauma without any detectable associated nerve lesion and CRPS type 2 (causalgia), involving a frank nerve injury. Both have similar symptomatology and are characterized by spontaneous pain that is disproportionate to the inciting event together with sensory, motor, autonomic and trophic changes ${ }^{1}$. Its incidence in the Netherlands is estimated at 26.2 per 100,000 persons per year, with women being more frequently impaired than men ${ }^{2}$. Physiopathogeny is complex, involving the central nervous system and peripheral neurogenic inflammatory processes $^{3}$. CRPS is a multifactorial disorder associated with an aberrant host response to tissue injury ${ }^{4}$. Diagnostic criteria ${ }^{5}$ rely on the clinical presentation. Specific additional diagnostic tests do not appear to be useful and often are expensive ${ }^{6}$. CRPS is frequently associated with substantial disability, loss of quality of life and personal and societal economic burden ${ }^{4}$. A combined pharmacological, interventional and psychological approach, in conjunction with a rehabilitation pathway, has been proposed for the management of CRPS. Pain reduction and restoration of function form the mainstay of therapy ${ }^{7}$. Spinal cord stimulation (SCS) seems to be an effective and safe treatment of CRPS- ${ }^{8-11}$. Despite the diminishing effect of SCS over time, $95 \%$ of patients with an implant would be willing to repeat the treatment for the same result (if it had not already been implanted $)^{12}$. The success of SCS depends on the use of strict criteria for selecting patients that are likely to respond to this treatment ${ }^{8}$. Unfortunately, necessary re-intervention as a result of technical problems with the implant are frequent, especially during the first two years following implantation ${ }^{9,13}$. Nevertheless, SCS seems to be cost-effective $\mathrm{e}^{10,12}$.

We here report a case of severe CRPS in a 31-year-old woman, who did not respond to the usual treatments, including anesthetic blocks. SCS brought relief of pain, allowing rehabilitation.

\section{Case description}

A 31-year-old white Caucasian woman suffering from repetitive ankle twisting underwent a second ligamentoplasty of the right ankle in 2008 for persisting instability. After intervention, she was treated with plaster-immobilization for seven weeks. Immediately after removal of the plaster, the patient reported intense pain and did not respond to standard painkillers (paracetamol, non-steroidal anti-inflammatory drugs and opioids), while physiotherapy became more and more difficult. Swelling of the right foot appeared, the scar re-opened and she presented with a dystonic posture of the right foot. Following an assessment by scintigraphy, possible CRPS was suspected. The diagnosis of CRPS-1 with dystonia was made and she was treated with several drugs, all of which were either without effect or poorly tolerated. A mobilization of the ankle was also performed under general anesthesia without long-lasting improvement.

In 2009, the patient was referred to a hospital where multidisciplinary management was started. Other treatments were tried, but without therapeutic benefits: dextropropoxyphene $(600 \mathrm{mg} / \mathrm{d})$, a buprenorphine patch $(26.25 \mu \mathrm{g} / \mathrm{h})$, hydromorphone $(12 \mathrm{mg} / \mathrm{d})$, clomipramine $(50 \mathrm{mg} / \mathrm{d})$, duloxetine $(60 \mathrm{mg} / \mathrm{d})$, pregabaline $(300 \mathrm{mg} / \mathrm{d})$, clonidine $(0.30 \mathrm{mg} / \mathrm{d})$, a lidocaine patch (2/day), intravenous pamidronate $(30 \mathrm{mg} / \mathrm{d})$ and methylprednisolone $(64 \mathrm{mg} / \mathrm{d})$. Three months later, the patient was referred to the Multidisciplinary Pain Center of CHU Mont-Godinne for administration of peridural and intrathecal anesthetic blocks (bupivacaine 5-15 mg). We noticed that the intrathecal block induced a contra-lateral motor block.

When the patient was transferred to the Multidisciplinary Pain Center of the Cliniques Universitaires Saint-Luc in Brussels two months later, she presented with pain in the entire right foot, irradiating to just under the knee. The pain was permanent and reported on average at $8-9 / 10$ on the VAS (Visual Analogue Scale). The patient described the pain as a burning feeling, which was enhanced by touch and mobilization. Walking required two canes, long distances necessitated a wheelchair. She also suffered from sleep and mood disturbances. Housekeeping was left to her husband and she took leave from her job at a child-care centre. Clinical examination showed a swollen foot and calf and tightened skin that was pale, gleaming and cold. The ankle was fixed in a dystonic equinus; only the toes presented active, though limited, movement of flexionextension. The range of motion of the knee and hip were normal. Neurological assessment showed hypoesthesia like a sock on the right foot (up to the shin), hyperesthesia and hyperalgesia on the leg (on and above the knee- with allodynia (mechanical and dynamic rather than static). It was almost impossible for the patient to bear touch to the painful region, which meant that a complete sensory assessment could not be realized (Figure 1). Evoked somesthetic potentials indicated normal lemniscal pathways coming from the lower limbs. The presence of a peripheral injury could not be evaluated because of the pain in the right leg.

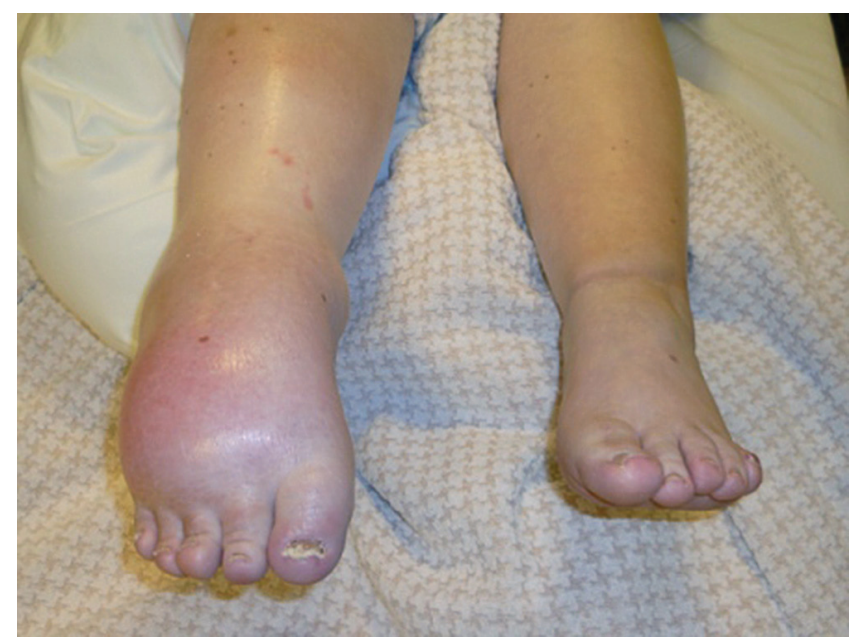

Figure 1. CRPS-1 (Complex regional pain syndrome): dystonic equinus of the right ankle, swollen foot and calf with tightened, pale, gleaming and cold skin. 
In our Multidisciplinary Pain Center, the patient underwent the following algological techniques in order to try starting rehabilitation:

- Intravenous ketamine (6 mg/h, increasing to $20 \mathrm{mg} / \mathrm{h}):$ no effect and handicapping side-effects (nausea, drowsiness).

- Two anesthetic peripheral blocks of the right sciatic nerve at the knee, guided by echography (ropivacaine $115 \mathrm{mg}$, lidocaine $100 \mathrm{mg}$, clonidine $75 \mu \mathrm{g}$ ): no anesthesia and persistence of pain.

- Patches of clonidine (400 $\mu \mathrm{g} / \mathrm{day})$ and local anesthetic (lidocaine 5\%) applied to the right foot: no effect.

- Anesthetic epidural block with a lateralized catheter. X-ray control with iohexol showed good epidural diffusion but injection of bupivacaine $(25 \mathrm{mg})$ and lidocaine $(100 \mathrm{mg})$ in combination with clonidine failed to produce any anesthesia or analgesia.

- Nine anesthetic intrathecal blocks using bupivacaine (5 to $13 \mathrm{mg}$ ), clonidine (60 to $75 \mu \mathrm{g})$ or baclofen $(50 \mu \mathrm{g})$ : no effect was found with $5 \mathrm{mg}$ of bupivacaine, a partial positive effect lasting a maximum $2 \mathrm{~h} 15 \mathrm{~min}$ for 10 to $13 \mathrm{mg}$ of bupivacaine as reported by the patient. Treatment by continuous infusion and bolus of clonidine and bupivacaine respectively had a partial effect but had to be interrupted because of post-lumbarpuncture-syndrome. Baclofen had no effect.

- Transcutaneous electrical nerve stimulation (TENS): the stimulations were not perceived below the knee, this treatment was thus ineffective.

Two months later, almost one year after onset of CRPS, the patient discontinued all analgesics because of lack of therapeutic benefits and side effects on her cognitive functions and personality. Subsequently, she start noticing an improvement in her mood and cognitive functioning. Pain and neuro-orthopedic status of the right leg remained the same. As she started to feel better mentally, she progressively broadened her activities and started spinning and hydrotherapy.

In 2010, almost one year later, SCS (epidural electrode, Medtronic ${ }^{\circledR}$, USA inserted percutaneously at lower lumbar level and pushed up to the T9 level) was trialled. During the testing period, we noticed a reduction in the intensity of hyperesthesia and allodynia of the right foot allowing touch and both active and passive mobilization of the foot, especially of the toes. Edema of the right foot decreased and vasodilation returned colouring the foot and warming it up. Importantly, the patient also experienced psychological relief. There was no effect on the equinus. After multidisciplinary discussion, it was decided to finally implant the pulse generator after about six weeks of testing.

At the time of writing this paper (2013), the patient is doing better. She has set up different strategies of coping, she is considering taking up her social life again and feels more optimistic about her future. Physiotherapy is now possible, but needs to be performed gently and progressively. Mobilization is performed during hydrotherapy. Orthopedic shoes have been manufactured in order to allow her to lean on her foot. Retrospectively, the Neuropathic Pain Symptom Inventory ${ }^{14}$ (NPSI), used to determine the quality of pain relieved by SCS showed a partial relief of both spontaneous pain and evoked pain (Figure 2). Laser evoked potentials (LEP) at one year after implantation of SCS showed a dysfunction of afferent small fibers $(\mathrm{A} \delta)$ from the right foot. No abnormalities where observed when stimulating the left foot and hand (Figure 3).

\section{Discussion}

About (9-49\%) of patients with CRPS suffer from movement disorders, including loss of voluntary control, bradykinesia, dystonia, myoclonus and tremor. Dystonia occurs in approximately $20 \%$ of patients with CRPS and is characterized by fixed flexion postures

Does your pain feel like burning?

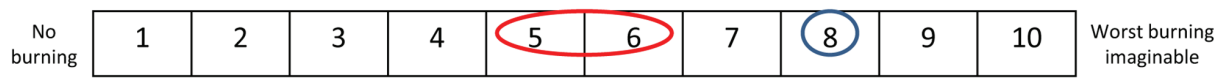

Does your pain feel like pressure?

\begin{tabular}{c|c|c|c|c|c|c|c|c|c|c|}
$\begin{array}{c}\text { No } \\
\text { pressure }\end{array}$ & 1 & 2 & 3 & 4 & 5 & 6 & 7 & 8 & 9 & 10 \\
$\begin{array}{c}\text { Worst } \\
\text { pressure } \\
\text { imaginable }\end{array}$
\end{tabular}

Is your pain provoked or increased by brushing on the painful area?

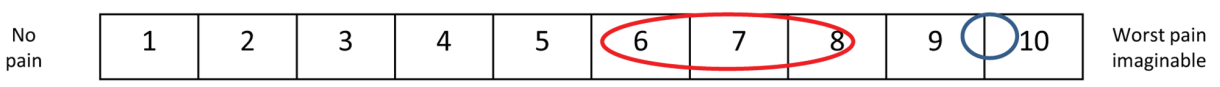

Is your pain provoked or increased by pressure on the painful area?

No
pain $\quad$\begin{tabular}{|l|l|l|l|l|l|l|l|l|l|}
\hline & 2 & 3 & 4 & 5 & 6 & 7 & 8 & 9 & 10 \\
\hline
\end{tabular}

Figure 2. Neuropathic Pain Symptom Inventory (NPSI) evaluating the effect of Spinal Cord Stimulation (SCS) on neuropathic pain. In blue, the spontaneous sensation is indicated, without the SCS functioning. The values for neuropathic pain when SCS is on are shown in red, indicating a global reduction of pain. 


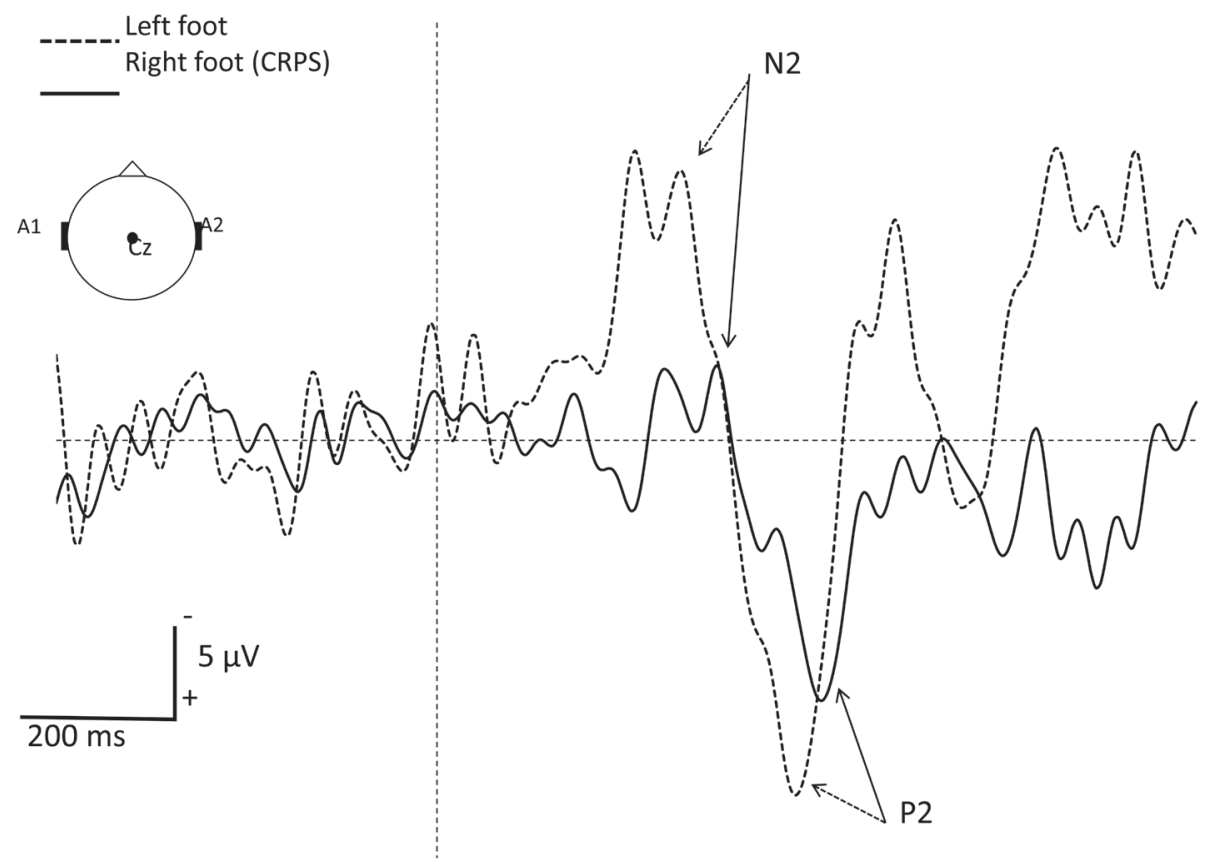

Figure 3. Grand average of A $\partial$-fiber related laser evoked potentials (LEP) recorded at the vertex (Cz vs. A1-A2) after stimulation of the right (CRPS side) and left foot dorsum. Note the increased latency and reduced amplitude of LEP components in the affected foot as compared to the contralateral side. The vertical interrupted line represents the onset of the $\mathrm{CO}_{2}$ laser stimulus (duration $50 \mathrm{~ms}$; surface area $79 \mathrm{~mm}^{2}$; intensity $9.7 \mathrm{~mJ} / \mathrm{mm}^{2}$ ). Each side received 30 stimuli with an interstimulus interval of 8 to $15 \mathrm{~s}$. The subject had to press a microswitch, held in her dominant hand, as fast as possible when perceiving the stimulus. To focus the patient's attention, each stimulus was announced of 1.5 to $3 \mathrm{~s}$ beforehand, allowing her to fixe her gaze with open eyes during \pm 4 seconds to avoid eye movement artefacts.

of the fingers, wrist and feet that may vary in severity ${ }^{15}$. The prevalence of movement disorders increases as the disease duration lengthens ${ }^{15}$. The pathogenesis of CRPS and its relation to dystonia remain poorly understood. The central and peripheral nervous systems as well as immunological ${ }^{16}$, psychological $^{4,15,17,18}$ and genetic ${ }^{19}$ factors seem to be implicated. We will only discuss neurological factors in this case report.

There is converging evidence for the role of the central nervous system in the physiopathogenesis of CRPS with dystonia. Central sensitization induced by tissue or nerve injury alters transmission and processing of peripheral sensorimotor input in the spinal cord. Associated with central disinhibition (both in the descending pathways and the brain itself), such changes set the stage for the development of movement disorders seen in CRPS ${ }^{15}$. Cortical involvement in CRPS is suggested by mislocalizations of tactile stimuli, changes of size and organization of the somatosensory map, changes in motor cortex representation and body perception disturbances ${ }^{20}$. The basal ganglia and parietal lobe seem especially related to some movement disorders such as dystonia and to hemineglect/inattention in CRPS ${ }^{21}$.

Regarding the peripheral nervous system, large nerve fibers (proprioceptive afferents) do not seem to explain the underlying mechanisms of dystonia related to CRPS-1. Indeed, Van Rijn et al. ${ }^{22}$ found no differences in somatosensory-evoked potentials (SSEP) in
CRPS-1 patients with dystonia compared to healthy controls after spatio-temporal stimulation (confirming the integrity of "cortical proprioceptive afferent processing"). In relation to our case report, we would like to highlight the role of small nerve fibers in CRPS (C and A $\delta$ ). Pathological studies on chronic CRPS-1 limbs show degeneration of small ( $\mathrm{C}$ and $\mathrm{A} \delta$ ) nerve fibers which serve nociceptive and autonomic functions ${ }^{4}$. However, this phenomenon does not seem to be specific to CRPS-1. Indeed, this degeneration is also seen in small-fiber-predominant polyneuropathies, which cause CRPS-like abnormalities ${ }^{23}$. Oaklander ${ }^{23}$ postulates that persistent CRPS-1 may represent a small-fiber-predominant mono- or oligoneuropathy that is initiated by a limb trauma. Moreover, dysfunction in small nerve fiber processing has been found by quantitative thermal testing in patients with CRPS-related dystonia ${ }^{24}$. On the other hand, patients with pure small-fiber polyneuropathies never develop dystonia, implying that neither small-fiber dysfunction nor its central consequences are a driving force behind dystonia ${ }^{25}$. Thus, it remains to be investigated whether nerve degeneration (i.e. dysfunction of small-diameter primary afferent nociceptor axons distal to trauma) causes CRPS-1 and/or dystonia ${ }^{4,17,24,25}$.

As such we do not have an unequivocal and clear explanation for the mechanism underlying dystonia in our CRPS-1 patient. However, LEP demonstrated dysfunction of small nerve fibers in the right foot is a possibility, as will be discussed in a later section of this article. 
A recent alternative neurological hypothesis proposed by Ethier et al. ${ }^{26}$, suggests a possible implication of the immune cells of the central nervous system, i.e. the microglia. These microglial could be activated in the brain as a result of a retrograde spread of neuroinflammation from the level of the spinal cord to the level of the motor cortex. As a consequence of microglial activation, functional changes may occur in the motor cortex. In predisposed individuals, these functional changes putatively trigger focal reduction of intracortical inhibition, a condition known to foster fixed dystonic postures. Further research in this area should help provide a better understanding of the mechanism underpinning CRPS-related dystonia.

Conventional therapies for the treatment of CRPS-1 with dystonia have poor efficacy. To our knowledge, there are no randomized controlled trials (RCT) of physical therapy, occupational therapy or pharmacotherapy in the treatment of movement disorders in CRPS $^{27}$. Strategies that enhance the central inhibitory state may benefit these patients ${ }^{15}$. In some patients, the dystonia associated with CRPS responds markedly to intrathecal baclofen, a specific $\gamma$-aminobutyric acid (GABA) receptor agonist that inhibits sensory input to the neurons of the spinal $\operatorname{cord}^{28}$. A rehabilitation program associating laterality recognition, mental imaging and mobilization in front of a mirror ${ }^{29}$ is effective at reducing pain and increasing functioning by restoring sensory-motor integration ${ }^{6}$. Most of these treatment options (including mirror visual feed-back) had been previously tried out by our patient, without delivering a satisfactory effect on pain relief or quality of life.

The same problem was noticed with interventional treatment (e.g. SCS). Over the last decade, only one other case of CRPS with resistance to local anesthetic blocks has been reported, involving a 12-year-old girl suffering from CRPS-1 of the right ankle ${ }^{30}$. The mechanism of resistance to anesthetic blocks is currently unknown. The authors of this report, Maneksha et al..$^{30}$, proposed that changes in the dorsal horn cells of the spinal cord, secondary to activation of N-methyl-D-aspartate (NMDA) receptors, may play a role in the pathophysiology of this pain syndrome. Our case provides further support for the importance of neural changes associated with CRPS-1. The implication, in various pain conditions, of voltagegated sodium channels, mainly isoforms $\mathrm{Na}(\mathrm{v}) 1.7$ and $\mathrm{Na}(\mathrm{v}) 1.8$, but also others of the nine isoforms ( $\mathrm{Na}(\mathrm{v}) 1-9)$, has been well demonstrated. For example, overexpression of different isoforms of $\mathrm{Na}(\mathrm{v})$ (at least 1.7) is suspected to play a key role in the physiopathology of radicular pain, post-herpetic neuralgia and trigeminal neuralgia ${ }^{31}$. In contrast, congenital deficiency of $\mathrm{Na}(\mathrm{v}) 1.7$ is associated with inherited insensitivity to pain $^{32}$. In severe CRPS-1 patients, these receptors are clearly upregulated in keratinocytes ${ }^{33}$. In the skin, their overexpression leads to neuronal hyperexcitability and pain, by increasing epidermal adenosine triphosphate (ATP) release and excessive activation of $\mathrm{P} 2 \mathrm{X}$ receptors ${ }^{33}$. Moreover, it has been shown that mutation of $\mathrm{Na}(\mathrm{v}) 1.7$, which increases excitability of sensory neurons, can lead to a decrease of sympathetic activity when expressed on sympathetic neurons ${ }^{32}$. A decrease in sympathetic activity, and a consequent increase of peripheral release of vasodilating peptides, leads to local changes such as erythema and edema, as seen in our patient. As a consequence, whether patients with CRPS-1 have an upregulation of $\mathrm{Na}(\mathrm{v})$ channels, at least
$\mathrm{Na}(\mathrm{v}) 1.7$, not only in keratinocytes, but also in the nervous system, may be worth investigating further.

Based on the inefficacy of potent $\mathrm{Na}(\mathrm{v})$ blockers (i.e. local anesthetics), we can indicate that major neurologic changes were present in our severe CRPS- 1 patient. On the basis of the observed lack of response to local anaesthetics at different levels, we suspect that these changes were not only present in the periphery, but also in the (sciatic) nerve trunk, and in the spinal cord.

Despite her (relative) resistance to anesthetic blocks, our patient was a good responder to SCS. The mechanism of action of SCS is still incompletely understood and is frequently debated (Table 1). The results of several studies, mostly on animal models but also in patients, suggest that the effect of SCS is to a large part mediated via $\mathrm{GABA}_{\mathrm{B}}$ and muscarinic $\mathrm{M}_{4}$ receptors ${ }^{34-37}$. SCS induces GABA and acetylcholine (Ach) release in the spinal dorsal horn ${ }^{38-40}$ and activates descending serotoninergic pathways ${ }^{41}$, all of which inhibit spinal nociception processing. In parallel, Truin et al. ${ }^{42}$ demonstrated the role of NMDA receptors in the effect of SCS. Indeed, the combined use of SCS and sub-effective doses of intrathecal ketamine (an antagonist of NMDA receptors) resulted in a significant conversion of non-responders to SCS to responders to SCS. This effect could not be investigated in our patient as those treatments had not been given simultaneously. Besides, SCS is thought to affect peripheral vasodilatation via antidromic activation of spinal afferent neurons and inhibition of sympathetic efferents (small fibers). This effect seems to be mediated by calcitonin gene-related peptide (CGRP) and possibly nitric oxide (NO) ${ }^{43}$.

Smits ${ }^{44}$ suggests that the selection and subdivision by severity of mechanical allodynia may provide better pre-treatment predictions of the possible therapeutic benefits of SCS. These results match with those of Van Eijs ${ }^{13}$ suggesting that brush-evoked allodynia may be a significant negative prognostic factor of SCS treatment outcome after one year in chronic CRPS-1. The chances of achieving and maintaining successful pain reduction drop from $81 \%$ to $31 \%$ if allodynia is present ${ }^{13}$. However this notion partially conflicts with our observations. In our patient allodynia evoked by brushing or pressure on the painful area was present before SCS was tested and evoked pain scores were partially relieved by SCS, according to the NPSI (Figure 2).

It is important to emphasize that the reason someone with chronic pain gets better has as much to do with the nonspecific effects of treatment as with the treatment itself ${ }^{45}$. For instance, why did most of the invasive techniques undergone by our patient have no effect? And why was modulation of pain by SCS possible later on? Much of this has to do with the particular aspects of the human brain and the individual's need to interpret pain ${ }^{46}$. Among those nonspecific treatment effects, factors that can impact on pain perception include patient-specific factors (degree of anxiety, desire to get better; improved coping etc.) and the interpersonal relationship between that person and their physician (perception of attention and caring ${ }^{47}$; major value of education, reassurance and counseling ${ }^{48}$; heightened expectations ${ }^{49}$ ). In the context of chronic pain patients who are challenging to treat, the importance of communication style is paramount $^{50}$. It is important to remember that empathy, mutual respect 
Table 1. Different factors implicated in the mechanism of action of spinal cord stimulation. A brief review of the literature, comparing studies on animals and on humans.

\begin{tabular}{|c|c|c|c|}
\hline Factor implicated & Reference & Animal studies & Human studies \\
\hline $\begin{array}{l}\text { NEUROPHYSIOLOGY } \\
\text { GABA receptor } \\
\text { (baclofen) }\end{array}$ & $\begin{array}{l}\text { Cui J et al. (Neurosci Lett, 1998) } \\
\text { Lind G et al. (Eur J Pain, 2004) } \\
\text { Lind G et al. (Eur J Pain, 2008) } \\
\text { Song Z et al. (Neurosci Lett, 2008) }\end{array}$ & \multicolumn{2}{|c|}{$\begin{array}{l}\text { The effect of SCS could be enhanced by the corresponding agonists of } \\
\text { GABA receptor and muscarinic receptor in animal models and in patients. }\end{array}$} \\
\hline $\begin{array}{l}\text { Muscarinic receptor } \\
\text { (Ach, oxotremorine) }\end{array}$ & $\begin{array}{l}\text { Cui J et al. (Pain, 1997) } \\
\text { Schechtman G et al. (Pain, 2008) } \\
\text { Schechtman G et al. (Anesth } \\
\text { Analg 2004) }\end{array}$ & $\begin{array}{l}\text { SCS can induce GABA and Ach } \\
\text { release, associated with diminished } \\
\text { release of glutamate and aspartate } \\
\text { in the spinal dorsal horn of animal } \\
\text { models of neuropathic pain. The } \\
\text { effect of SCS is to a large part } \\
\text { mediated via GABA }{ }_{B} \text { and muscarinic } \\
\mathrm{M}_{4} \text { receptors. }\end{array}$ & $N / A$ \\
\hline $\begin{array}{l}\text { GABA receptor } \\
\text { (Serotonine) }\end{array}$ & Song Z et al. (Pain, 2009) ${ }^{41}$ & $\begin{array}{l}\text { A rat model of mononeuropathy } \\
\text { showed evidence that SCS activates } \\
\text { the descending serotonergic } \\
\text { pathways that may inhibit spinal } \\
\text { nociceptive processing partially via } \\
\text { GABAergic link. }\end{array}$ & $N / A$ \\
\hline $\begin{array}{l}\text { NMDA receptor } \\
\text { (antagonist Ketamine) }\end{array}$ & Truin M. (Eur J Pain, 2011) & $N / A$ & $\begin{array}{l}\text { The combined treatment of SCS and } \\
\text { sub-effective doses of intrathecal } \\
\text { ketamine in non-responders } \\
\text { resulted in a significant reduction } \\
\text { of the withdrawal threshold in all } \\
\text { previous non-responders to SCS, } \\
\text { thereby converting them into } \\
\text { responders to SCS. }\end{array}$ \\
\hline $\begin{array}{l}\text { Spinal sympathic } \\
\text { efferents (small fibers) }\end{array}$ & Prager J. (Pain Med, 2010) ${ }^{43}$ & $\begin{array}{l}\text { Animal models of peripheral } \\
\text { vasodilatation affected by SCS have } \\
\text { shown the involvement of antidromic } \\
\text { release of CGRP and possibly NO } \\
\text { from small-diameter sensory neurons } \\
\text { expressing the TRPV1 receptor. } \\
\text { ERK may be an important signaling } \\
\text { intermediary in this vasodilatary } \\
\text { response to SCS and in animal } \\
\text { models of neuropathic pain. }\end{array}$ & $\begin{array}{l}\text { The involvement of sympathetic } \\
\text { efferences in the vasodilatary } \\
\text { response to SCS has been } \\
\text { demonstrated in models of angina } \\
\text { pectoris in patients. }\end{array}$ \\
\hline \multirow[t]{2}{*}{$\begin{array}{l}\text { CLINICAL } \\
\text { EXAMINATION: }\end{array}$} & Smits $\mathrm{H}$ et al. (Neuroscience, 2006) & \multirow[t]{2}{*}{$N / A$} & $\begin{array}{l}\text { The selection and subdivision } \\
\text { of patient groups following the } \\
\text { severity of mechanical allodynia } \\
\text { may provide better pre-treatment } \\
\text { prediction of possible therapeutic } \\
\text { benefits of SCS. }\end{array}$ \\
\hline & Van Eijs F et al. (Eur J Pain, 2010) & & $\begin{array}{l}\text { Brush-evoked allodynia may be } \\
\text { a significant negative prognostic } \\
\text { factor of SCS treatment outcome } \\
\text { after one year in chronic CRPS- } 1 \text {. }\end{array}$ \\
\hline
\end{tabular}

GABA $=\gamma$-amino-butiric acid, Ach $=$ Achetylcholine, NMDA $=$ N-methyl-D-aspartic acid, CGRP $=$ calcitonin gene-related peptide, NO $=$ nitric oxide, TRPV1 $=$ transient receptor potential vanilloïde 1, ERK = extracellular signal-regulated kinase. 
and an open doctor-patient collaboration in the treatment are excellent skills in the interaction with patients ${ }^{51}$. Jamison ${ }^{45}$ suggests that the therapeutic quality of the practitioner's manner and the role of the patient's expectations of treatment are very powerful. We need to maximize those nonspecific effects of care in reducing the suffering of individuals with pain.

This case suggests the importance of behavioral change as part of the treatment of CRPS. First, the patient expected an explanation of her illness based on the bio-medical model ${ }^{52}$. This concept postulates that disease is fully accounted for by deviations from the norm of measurable biological (somatic) variables. A complex phenomenon is ultimately derived from a single primary principle (reductionism) and the mental component is separated from the somatic component (dualism, specifically psychophysic parallelism). Progressively, helped by a psychosocial accompaniment conducted by a clinical psychologist, her conception of illness converted into a bio-psycho-social model, accounting for human experiences besides the somatic abnormalities. That psychological work seemed to be necessary before trying out the SCS, even if, in this case, it remains, at least partially, hypothetical. Nevertheless, we propose that the bio-psycho-social model of rehabilitation in the treatment of CRPS would be an important step for achieving a change of behavior to acceptation of a disabling situation.

Finally, the LEP realized on our patient suggest pathology of the small fibers ( $\mathrm{C}$ and $\mathrm{A} \delta$ ). Whether this is the cause or the result of CRPS is uncertain. To our knowledge, no article has been published exploring the link between LEP results and the outcome of treatment by SCS in CRPS-patients. This is an interesting topic for future research.

\section{Conclusion}

The resistance of pain to anesthetic blocks at different levels of the nervous system and the favorable response to SCS emphasizes the complexity of the pathophysiology of CRPS associated with dystonia in our case. This case is also notable because of its complex presentation: initial resistance to several treatments with subsequent reduction of pain by SCS. This poses the interesting question of the role of nonspecific treatment effects. Finally, it illustrates the importance of the bio-psycho-social model.

\section{Consent}

Consent for the publication of clinical details and images was obtained from the patient.

\section{Author contributions}

$\mathrm{CV}, \mathrm{BLPDW}, \mathrm{PF}$ and EM were involved in the patient's care. $\mathrm{CV}$ and EM analyzed the patient's data and discussed these with BLPDW, PF and RD. All the authors were involved in the manuscript preparation and approved the final version.

\section{Grant information}

The author(s) declared that no grants were involved in supporting this work.

\section{Acknowledgements}

The authors would like to thank Prof. L. Plaghki for his contribution to this article. The execution and critical analysis of LEP were performed under his direction. The authors have no conflict of interest to declare.
1. Wasner G, Schattschneider J, Binder A, et al.: Complex regional pain syndrome-diagnostic, mechanisms, CNS involvement and therapy. Spinal Cord. 2003; 41(2): 61-75.

PubMed Abstract | Publisher Full Text

2. de Jong J, Vlaeyen J, Onghena P, et al:: Reduction of pain-related fear in complex regional pain syndrome type I: the application of graded exposure in vivo. Pain. 2005; 116(3): 264-75. PubMed Abstract | Publisher Full Text

3. Shipton E: Complex regional pain syndrome - mechanisms, diagnosis and management. Curr Anaesth Crit. 2009; 20(5): 209-14. Publisher Full Text

4. Marinus J, Moseley L, Birklein F, et al.: Clinical features and pathophysiology of complex regional pain syndrome. Lancet Neurol. 2011; 10(7): 637-48. PubMed Abstract | Publisher Full Text

5. Harden R, Bruehl S, Stanton-Hicks M, et al.: Proposed new diagnostic criteria for complex regional pain syndrome. Pain Med. 2007; 8(4): 326-31. PubMed Abstract | Publisher Full Text

6. Berquin $A$ : Progrès récents dans le diagnostic et le traitement du syndrome douloureux régional complexe. Rev Med Suisse. 2008; 4(162): 1514-519. Reference Source
7. Albazaz R, Wong Y, Homer-Vanniasinkam S: Complex regional pain syndrome: a review. Ann Vasc Surg. 2008; 22(2): 297-306. PubMed Abstract | Publisher Full Text

8. Kemler M, Barendse G, van Kleef M, et al: Spinal cord stimulation in patients with chronic reflex sympathetic dystrophy. N Engl J Med. 2000; 343(9): 618-24. PubMed Abstract | Publisher Full Text

9. Turner J, Loeser J, Deyo R, et al:: Spinal cord stimulation for patients with failed back surgery syndrome or complex regional pain syndrome: a systematic review of effectiveness and complications. Pain. 2004; 108(1-2): 137-47. PubMed Abstract | Publisher Full Text

10. Taylor R, Van Buyten JP, Buchser E: Spinal cord stimulation for complex regional pain syndrome: a systematic review of the clinical and cost-effectiveness literature and assessment of prognostic factors. Eur J Pain. 2006; 10(2): 91-101.

PubMed Abstract | Publisher Full Text

11. Mailis-Gagnon A, Furlan AD, Sandoval JA, et al:: Spinal cord stimulation for chronic pain. Cochrane Database Syst Rev. 2004; 3(3): CD003783. PubMed Abstract | Publisher Full Text

12. Kemler M, de Vet H, Barendse G, et al.: Effect of spinal cord stimulation for chronic complex regional pain syndrome Type I: five-year final follow-up of 
patients in a randomized controlled trial. J Neurosurg. 2008; 108(2): 292-98. PubMed Abstract | Publisher Full Text

13. van Eijs F, Smits H, Geurts J, et al: Brush-evoked allodynia predicts outcome of spinal cord stimulation in complex regional pain syndrome type 1. Eur $J$ Pain. 2010; 14(2): 164-69.

PubMed Abstract | Publisher Full Text

14. Bouhassira D, Attal N, Fermanian J, et al:: Development and validation of the Neuropathic Pain Symptom Inventory. Pain. 2004; 108(3): 248-57. PubMed Abstract | Publisher Full Text

15. van Hilten $\mathrm{J}$ : Movement disorders in complex regional pain syndrome. Pain Med. 2010; 11(8): 1274-277.

PubMed Abstract | Publisher Full Text

16. de Rooij AM, Florencia Gosso M, Haasnoot GW, et al.: HLA-B26 and HLA-DQ8 are associated with Complex Regional Pain Syndrome with fixed dystonia. Pain. 2009; 145(1-2): 82-5.

PubMed Abstract | Publisher Full Text

17. Lang A, Chen R: Dystonia in complex regional pain syndrome type 1. Ann Neurol. 2010; 67(3): 412-14.

Publisher Full Text

18. Reedijk W, van Rijn M, Roelofs K, et al.: Psychological features of patients with complex regional pain syndrome type 1 related dystonia. Mov Disord. 2008; 23(11): 1551-559.

PubMed Abstract | Publisher Full Text

19. Gosso M, de Rooij A, Alsina-Sanchis E, et al:: Systematic mutation analysis of seven dystonia genes in complex regional pain syndrome with fixed dystonia. J Neurol. 2010; 257(5): 820-24.

PubMed Abstract | Publisher Full Text

20. Swart C, Stins J, Beek $P$ : Cortical changes in complex regional pain syndrome (CRPS). Eur J Pain. 2009; 13(9): 902-07. PubMed Abstract | Publisher Full Text

21. Lebel $A$, Becerra $L$, Wallin $D$, et al.: fMRI reveals distinct CNS processing during symptomatic and recovered complex regional pain syndrome in children. Brain 2008: 131(Pt 7): 1854-879. PubMed Abstract | Publisher Full Text

22. van Rijn M, van Hilten J, van Dijk J: Spatiotemporal integration of sensory stimuli in complex regional pain syndrome and dystonia. J Neural Transm. 2009; 116(5): 559-65.

PubMed Abstract | Publisher Full Text

23. Oaklander $\mathrm{A}$, Fields $\mathrm{H}$ : Is reflex sympathetic dystrophy/complex regional pain syndrome type 1 a small-fiber neuropathy? Ann Neurol. 2009; 65(6): 629-38. PubMed Abstract | Publisher Full Text

24. Munts A, van Rijn M, Geraedts E, et al:: Thermal hypesthesia in patients with complex regional pain syndrome related dystonia. J Neural Transm. 2011; 118(4): 599-603.

PubMed Abstract | Publisher Full Text | Free Full Text

25. Cooper M: Nerve injuries and the fixed dystonias of CRPS. Pain Med. 2011 12(5): 842-43.

PubMed Abstract | Publisher Full Tex

26. Ethier C, Brizzi L, Giguere D, et al.: Corticospinal control of antagonistic muscles in the rat. Eur J Neurosci. 2007; 26(6): 1632-641. PubMed Abstract | Publisher Full Text

27. Geertzen J, Perez R, Dijkstra P, et al.: EBGD Guidelines CRPS type I 2006. [Netherlands Association of Posttraumatic Dystrophy Patients]. Reference Source

28. van Hilten $\mathrm{J}$, van de Beek W, Hoff J, et al.: Intrathecal baclofen for the treatment of dystonia in patients with reflex sympathetic dystrophy. N Engl J Med. 2000; 343(9): 625-30

PubMed Abstract | Publisher Full Text

29. Moseley L: Graded motor imagery is effective for long-standing complex regional pain syndrome: a randomized controlled trial. Pain. 2004; 108(1-2): 192-98.

PubMed Abstract | Publisher Full Text

30. Maneksha F, Mirza H, Poppers P: Complex regional pain syndrome (CRPS) with resistance to local anesthetic block: a case report. J Clin Anesth. 2000; 12(1): 67-71. PubMed Abstract | Publisher Full Text

31. Siqueira S, Alves B, Malpartida $\mathrm{H}$, et al:: Abnormal expression of voltagegated sodium channels Nav1.7, Nav1.3 and Nav1.8 in trigeminal neuralgia. Neuroscience. 2009; 164(2): 573-77. PubMed Abstract | Publisher Full Text

32. Cummins $\mathrm{T}$, Sheets $\mathrm{P}$, Waxman $\mathrm{S}$ : The roles of sodium channels in nociception implications for mechanisms of pain. Pain. 2007; 131(3): 243-57. PubMed Abstract | Publisher Full Text | Free Full Text
33. Zhao P, Barr T, Hou Q, et al.: Voltage-gated sodium channel expression in rat and human epidermal keratinocytes: evidence for a role in pain. Pain. 2008; 139(1): 90-105.

PubMed Abstract | Publisher Full Text

34. Cui J, Meyerson B, Sollevi A, et al.: Effect of spinal cord stimulation on tactile hypersensitivity in mononeuropathic rats is potentiated by simultaneous GABA(B) and adenosine receptor activation. Neurosci Lett. 1998; 247(2-3): 183-86.

PubMed Abstract | Publisher Full Text

35. Lind G, Meyerson B, Winter J, et al:: Intrathecal baclofen as adjuvant therapy to enhance the effect of spinal cord stimulation in neuropathic pain: a pilot study. Eur J Pain. 2004; 8(4): 377-83.

PubMed Abstract | Publisher Full Text

36. Lind G, Schechtmann G, Winter J, et al.: Baclofen-enhanced spinal cord stimulation and intrathecal baclofen alone for neuropathic pain: Long-term outcome of a pilot study. Eur J Pain. 2008; 12(1): 132-36.

PubMed Abstract | Publisher Full Text

37. Song Z, Meyerson B, Linderoth B: Muscarinic receptor activation potentiates the effect of spinal cord stimulation on pain-related behavior in rats with mononeuropathy. Neurosci Lett. 2008; 436(1): 7-12.

PubMed Abstract | Publisher Full Text

38. Cui J, O'Connor W, Ungerstedt U, et al.: Spinal cord stimulation attenuates augmented dorsal horn release of excitatory amino acids in mononeuropathy via GABAergic mechanism. Pain. 1997; 73(1): 87-95.

PubMed Abstract | Publisher Full Text

39. Schechtmann G, Song Z, Ultenius $C$, et al.: Cholinergic mechanisms involved in the pain relieving effect of spinal cord stimulation in a model of neuropathy. Pain. 2008; 139(1): 136-45.

PubMed Abstract | Publisher Full Text

40. Schechtman G, Wallin J, Meyerson B, et al:: Intrathecal clonidine potentiates suppression of tactile hypersensitivity by spinal cord stimulation in a model of neuropathy. Anesth Analg. 2004; 99(1): 135-39.

PubMed Abstract | Publisher Full Text

41. Song Z, Ultenius C, Meyerson B, et al.: Pain relief by spinal cord stimulation involves serotoninergic mechanisms: an experimental study in a rat model of mononeuropathy. Pain. 2009; 147(1-3): 241-48.

PubMed Abstract | Publisher Full Text

42. Truin M, Janssen SP, van Kleef M, et al:: Successful pain relief in non-responders to spinal cord stimulation: the combined use of ketamine and spinal cord stimulation. Eur J Pain. 2011; 15(10): 1049.e1-9. PubMed Abstract | Publisher Full Text

43. Prager $\mathrm{J}$ : What does the mechanism of spinal cord stimulation tell us about complex regional pain syndrome? Pain Med. 2010; 11(8): 1278-283. PubMed Abstract | Publisher Full Text

44. Smits $\mathrm{H}$, Ultenius $\mathrm{C}$, Deumens $\mathrm{R}$, et al.: Effect of spinal cord stimulation in an animal model of neuropathic pain relates to degree of tactile "allodynia". Neuroscience. 2006; 143(2): 541-46. PubMed Abstract | Publisher Full Text

45. Jamison R: Nonspecific treatment effects in pain medicine. Pain Clinical Updates. 2011; XIX(2).

Reference Source

46. Wiech K, Ploner M, Tracey I: Neurocognitive aspects of pain perception. Trends Cogn Sci. 2008; 12(8): 306-13.

PubMed Abstract | Publisher Full Text

47. Jamison R, Raymond S, Levine J, et al:: Electronic diaries for monitoring pain: 1-year validation study. Pain. 2001; 91(3): 277-85

PubMed Abstract | Publisher Full Text

48. Barsky A: Palliation and symptomatic relief. Arch Intern Med. 1986; 146(5): 905-09.

PubMed Abstract | Publisher Full Text

49. Roberts A, Kewman D, Mercier L, et al.: The power of nonspecific effects in healing: implications for psychological and biological treatments. Clin Psychol Rev. 1993; 13(5): 375-91. Publisher Full Text

50. Tam M, Su M: How to manage difficult patients. 2006. Reference Source

51. Elder N, Ricer R, Tobias B: How respected family physicians manage difficult patient encounters. J Am Board Fam Med. 2006; 19(6): 533-41. PubMed Abstract | Publisher Full Text

52. Engel G: The need for a new medical model: a challenge for biomedicine. Science. 1977; 196(4286): 129-36. PubMed Abstract | Publisher Full Text 


\section{Open Peer Review}

\section{Current Peer Review Status:}

\section{Version 1}

Reviewer Report 09 September 2014

https://doi.org/10.5256/f1000research.4040.r5717

(C) 2014 Erdek M. This is an open access peer review report distributed under the terms of the Creative Commons Attribution License, which permits unrestricted use, distribution, and reproduction in any medium, provided the original work is properly cited.

\section{Michael Erdek}

Department of Anesthesiology \& Critical Care Medicine, John Hopkins University, Baltimore, MD, USA

There are two comments I have regarding the submission:

In the case description, the authors mention mobilization of the foot by a physiotherapist was not possible. Can they be more specific as to why that was the case?

In the Discussion, you mention that $9-49 \%$ of CRPS patients suffer from movement disorders. What is your source for that figure?

Competing Interests: No competing interests were disclosed.

I confirm that I have read this submission and believe that I have an appropriate level of expertise to confirm that it is of an acceptable scientific standard.

Reviewer Report 22 July 2014

https://doi.org/10.5256/f1000research.4040.r5167

(C) 2014 van Eijs F. This is an open access peer review report distributed under the terms of the Creative Commons Attribution License, which permits unrestricted use, distribution, and reproduction in any medium, provided the original work is properly cited.

\section{Frank van Eijs}

Department of Anaesthesiology, Sint Elisabeth Hospital, Tilburg, The Netherlands

The authors describe an interesting but not infrequently occurring case of therapy resistant CRPS. The report is well described. Only few issues need to be addressed. 


\section{Introduction}

"involving a frank nerve injury" may be replaced by "involving a detectable large fiber nerve injury"

\section{Case description}

"in 2008.." add the month

"In 2009..." add the month

"the patient reported intense pain and did not respond to"... replace and with which

"Subsequently she start noticing..." replace start with started

\section{Discussion}

Explain P2X receptors

"It is important to emphasize that the reason why someone with chronic pain gets better..."

"factors that can impact..." replace can with may.

In conclusion: although it's scientific value is of minor importance because of the nature of the article (being a case report), the report certainly is worth indexing.

F. van Eijs, MD, PhD

Competing Interests: No competing interests were disclosed.

I confirm that I have read this submission and believe that I have an appropriate level of expertise to confirm that it is of an acceptable scientific standard.

The benefits of publishing with F1000Research:

- Your article is published within days, with no editorial bias

- You can publish traditional articles, null/negative results, case reports, data notes and more

- The peer review process is transparent and collaborative

- Your article is indexed in PubMed after passing peer review

- Dedicated customer support at every stage

For pre-submission enquiries, contact research@f1000.com 